\title{
ENABLING MLEARNING TECHNOLOGIES INTO INTEGRATING OFF-CAMPUS INTERNSHIP AND CAPSTONE COURSES FOR TECHNOLOGICAL UNIVERSITY IN TAIWAN
}

\author{
Su-Chang Chen ${ }^{1}$, Hsi-Chi $\mathrm{Hsiao}^{2}$, Jen-Chia Chang ${ }^{3}$ and Dyi-Cheng $\mathrm{Chen}^{4}$ \\ ${ }^{1}$ Professor, Department of Marketing and Logistics Management, National Penghu University of Science and \\ Technology, Taiwan \\ ${ }^{2}$ Chair Professor, Department of Business Administration, Cheng Shiu University, Taiwan \\ ${ }^{3}$ Professor, Graduate Institute of Technological and Vocational Education, National Taipei University of Technology, \\ Taiwan \\ ${ }^{4}$ Professor, Department of Industrial Education and Technology, National Changhua University of Education, \\ Taiwan
}

\begin{abstract}
The purpose of this study is to develop a concept model of integrating off-campus internships and capstone courses through mLearning technologies. There are five steps of this concept model. The first step is to develop the teaching objectives and digital teaching material for the integration of off-campus internships and capstone course in the technological universities. The second one is to introduce the business mentors to join the teaching plan for integrating of off-campus internships and capstone course. The third one is to design a pretest-posttest control group experimental design. The experiment group uses our course design and based the mlearning technologies to achieve the teaching strategy. Then, the study will compare the result of two groups in pretest and posttest. It will take the pretest scores of employability skills for experiment group as covariates. Finally, it will use ANCOVA analysis to understand whether students can effectively enhance the employability skills through mLearning teaching strategies during off-campus internship and capstone courses.
\end{abstract}

\section{KEYWORDS}

Mlearning Technologies, Off-campus Internship, Capstone, Teaching Strategies

\section{INTRODUCTION}

Universities across the world are increasingly placing an emphasis on students' gained employability skills within the school curriculum, which should lead them into employment market (Filho, Shiel and Paço, 2016; Hsiao et al., 2019). Therefore, Teichler (2000) deemed that universities should design practical curriculum to shorten the gap between schools and industry. Unfortunately, Taiwan's technological universities rarely considered about developing their curriculum and fail to cultivate talents that reached the needs of industry (Hsiao \& Chen, 2001; Hsiao et al.,2012; Hsiao et al., 2019). Walmsley, Thomas and Jameson (2006) said that off-campus internship allowed students to have a deeper understanding of the workplace environment of small- and medium-sized enterprises and to learn valuable work experience. Aggrett and Busby (2011) believed that off-campus internship programs must be highly designed relevant to industry, so that students may learn professional skills and knowledge to satisfy industry's needs. Chen (2018) found that among the 28 technological universities in Taiwan, 24 schools $(85.7 \%)$ said that there were no teaching materials for their off-campus internship course, indicating that teachers had no established content. It can even be said that most teachers did not conduct actual teaching behavior except for visits.

Capstone is a course aiming to cultivate students' cognitive ability, learning motivation, and self-organization ability (Kostromina \& Gnedykh, 2016). All technological universities in Taiwan had set up a capstone course, which was an important component of professional courses in each department 
(Wang \& Lin, 2001). Chen et al. (2013) argued that the current teaching of capstone course in Taiwan paid too much attention to content in textbooks and ignored the industry's demands for practical technology, innovation, and problem-solving ability. Tang and Huang (2007) considered that universities could promote capstone courses through university-industry cooperation to reduce the gap between learning and application. If students participated in off-campus internship system, they may observe or understand practical business problems. When they returned to school, they could use business problems as their topics for capstone. Under the guidance of school professors and business mentors, they could slove the actual problems of enterprises. In this regard, it is necessary and important to integrate off-campus internship and capstone courses to cultivate students' practical capacity for technological universities in Taiwan. But the students' off-campus internships are scattered all over the place, it is not easy to collect face-to-face discussions. Therefore, it can use the mLearning technologies to discuss between instructor and students. In addition, business mentors who guide students' capstone topic cannot go to school at any time, and it is very important to use elearning technology.

The purpose of this study is to develop a concept model of integrating off-campus internships and capstone courses through mLearning technologies.

\section{THE CONCEPT MODEL}

There are five steps of our concept model.

The first step of this concept model is to develop the teaching objectives and digital teaching materials for the integration of off-campus internships and capstone course in the technological universities.

The second step is to introduce the business mentors to join teaching plan for integrating of off-campus internships and capstone course.

Thirdly, the study will design a pretest-posttest control group experimental design. The one class will assign as the experiment group. The other class will assign as the control group. The experiment group uses our course design and based the mlearning technologies to achieve the teaching strategy. The control group use traditional manner. All of the subjects will take the pretest and posttest of employability skills.

Fourth, the study will compare the results of two groups in pretest and posttest. It will take the pretest scores of employability skills for experiment group as covariates.

Finally it will use ANCOVA analysis to understand whether students can effectively enhance the employability skills through mlearning teaching strategies during off-campus internship and capstone courses.

\section{FUTURE WORK}

This is a work in process. The future work of this study is:

1. To accomplish the teaching objectives and digital teaching materials for the integration of off-campus internships and capstone course in the technological universities.

2. To invite the business mentors to join teaching plan for integrating of off-campus internships and capstone course.

3. To ask the experimental students to join this research.

4. To find a suitable employability skills scale.

\section{ACKNOWLEDGEMENT}

The authors would like to acknowledge the financial support of the National Science Council, Taiwan for the contract number of MOST 106-2516-S-346-001. 


\section{REFERENCES}

Aggett, M., and Busby, G. 2011. Opting out of internship: Perceptions of hospitality, tourism and events management undergraduates at a British University. Journal of Hospitality, Leisure, Sport and Tourism Education, 10(1), 106-113.

Chen, C. P., Chang, W. H., Hsiao, Y. L., and Yang, J. S. 2013. The construction of the industry-oriented special production capability project and curriculum connotation of the mechanical engineering in higher vocational colleges. Secondary Education, 64(1), 85-102.

Chen, S. C. 2018. "Curriculum planning, materials development and teaching experiment for integrating off-campus internship and capstone courses in department of marketing and logistics for technological universities: Using project-based learning to cultivate students' skill. Grant project research first year mid-report," Taiwan Ministry of Science and Technology, Grant project number: MOST 106-2511-S-346-001-MY3.

Filho, W. L., Shiel, C., Paço, A. 2016. Implementing and operationalising integrative approaches to sustainability in higher education: the role of project-oriented learning. Journal of Cleaner Production, 133, 126-135.

Hsiao H. C., Chen S. C., Chang J. C., Chen D. C., and Chou C. M. 2019. Teaching process guideline of industry-oriented off-campus internship curriculum for technological university. International Conference on Education and Development 2019. Portugal: Porto.

Hsiao H. C., Chen S. C., Chang J. C., Chou C. M., Chen C. P., Shen C. H. 2012. Developing and evaluating teaching material for entrepreneurship management course. 2012 Exploring Leadership and Learning Theories in Asia International Conference. Malaysia: Langkawi.

Hsiao, H. C., and Chen, S. C. 2001. Process of curriculum development for engineering education. $2^{\text {nd }}$ Russian Seminar on Engineering Education, UICEE: Tambov, Russia.

Kostromina, S., and Gnedykh, D. 2016. Students' psychological characteristics as factor of effective acquisition of visual information in E-learning. Procedia-Social and Behavioral Sciences, 217, 34-41.

Tang, Z. L., and Huang, M. F. 2007. The relationship between the special production courses of colleges and universities and industrial needs: taking the mechanical field as an example," Educational practice and Research, 20(2), 157-186.

Teichler, U. 2000. New perspectives of the relationships between higher education and employment, Tertiary Education and Management, No.6, 79-92.

Wang, J. H., and Lin, Q. F. 2001. Discussion on the teaching of special topics in technical colleges. Technical and Vocational Education Bimonthly, 63, 33-36.

Walmsley, A., Thomas, R., and Jameson, S. 2006. Surprise and sense-making: Undergraduate placement experiences in SMEs. Education+Training, 48, 360-372. 